\title{
The fate of Eichbornia azurea (Sw.) Kunth. detritus within a tropical reservoir
}

\author{
O destino dos detritos de Eichhornia azurea (Sw.) Kunth. em um reservatório tropical
}

Marcela Bianchessi da Cunha Santino ${ }^{1}$, Irineu Bianchini Jr. ${ }^{1,2}$ and Marco Hiroshi Okawa ${ }^{1}$

${ }^{1}$ Departamento Hidrobiologia, Universidade Federal de São Carlos - UFSCar, Rod. Washington Luiz, Km 235, CEP 13565-905, São Carlos, SP, Brazil e-mail: cunha_santino@ufscar.br, marcokawa@zip.ail.com.br

${ }^{2}$ Programa de Pós-graduação Ecologia e Recursos Naturais, Universidade Federal de São Carlos - UFSCar, Rod. Washington Luiz, Km 235, CEP 13565-905, São Carlos, SP, Brazil

e-mail: irineu@ufscar.br

\begin{abstract}
Aim: This study is aimed at comparing the kinetics of decomposition of Eichhornia azurea and discussing the fate of its detritus; Methods: The samples of aquatic macrophytes and water were collected in the Piraju Reservoir (São Paulo State, Brazil). The plant material was oven-dried and triturated and for each experimental condition (aerobic and anaerobic), 72 mineralization chambers were prepared with plant fragments and reservoir water. On sampling days the particulate and dissolved organic matter were quantified (on carbon basis POC and DOC, respectively); Results: The decomposition of E. azurea is more efficient under aerobic conditions, being 2.2 times faster than for the anaerobic process, according to the amount of mineralized carbon. For the decay of leaves, stems and roots of E. azurea the aerobic processes were 1.22-fold faster. It is assumed that the fractions responsible for the high oxygen consumption have reduced periods of half-time, and therefore do not accumulate in the ecosystems. Owing to the biomass of E. azurea in the Piraju Reservoir, the aerobic decay of E. azurea can promote moderate depletion in the dissolved oxygen budget. With the rate of the mineralization of refractory materials ( $\equiv$ half-time varying from 385 to 462 days), the fibrous debris of this plant, i.e. refractory fractions, associated with the appropriate conditions of $\mathrm{pH}$ and oxi-reduction potential, can contribute to the gas production and storage of particulate organic matter in sediments.
\end{abstract}

Keywords: decomposition, aquatic macrophytes, kinetic model, mineralization, Piraju Reservoir.

Resumo: Objetivo: Nesse estudo foram comparadas as cinéticas de decomposição de Eichhornia azurea e discutidos os destinos de seus detritos; Métodos: As amostras de plantas e de água foram coletadas no reservatório de Piraju (Estado de São Paulo, Brasil). As plantas foram secas e trituradas; para cada condição experimental (meio aeróbio e anaeróbio) foram preparadas 72 câmaras de mineralização com fragmentos de planta e água do reservatório. Nos dias de coleta as fraçôes particuladas e dissolvidas de matéria orgânica foram quantificadas (em base de carbono: carbono orgânico particulado (COP) e dissolvido (COD), respectivamente); Resultados: Com base no carbono mineralizado, os resultados indicaram que a decomposição de $E$. azurea foi mais eficiente em meio aeróbio (2,2 vezes mais rápido) que em anaerobiose. Para a decomposição das folhas, talos e raízes os processos aeróbios foram 1,22 vezes mais rápidos. Verificou-se que as fraçóes responsáveis pelos consumos elevados de oxigênio possuem tempos de meia vida reduzidos e, desse modo, não se acumulam no reservatório. Devido à biomassa de E. azurea no reservatório de Piraju os processos aeróbios de decomposição dessa espécie podem promover depleçôes moderadas no balanço de oxigênio dissolvido. Devido à magnitude dos coeficientes de degradação (meia-vida: de 385 a 462 dias), associados com as condições predominantes de $\mathrm{pH}$ e potencial de oxi-redução, as fraçôes refratárias dos detritos (fibras) de E. azurea podem contribuir para a produçáo de gases e no estoque de matéria orgânica particulada dos sedimentos do reservatório.

Palavras-chave: decomposição, macrófitas aquáticas, modelo cinético, mineralização, Reservatório de Piraju. 


\section{Introduction}

Aquatic macrophytes play important roles in chemical, physical and biological processes within aquatic ecosystems (Wetzel, 2001). In tropical reservoirs, floating macrophytes occupy extensive areas and their excessive quantities may cause a decrease on the potential of multiple uses (Thomaz and Bini, 1999). Several species of aquatic macrophytes grow in natural and manmade freshwater ecosystems in tropical regions, with an excess presence being noted for Egeria spp, Eichhornia crassipes, Oxycaryum cubense (= Scirpus cubenses), Pistia stratiotes, Salvinia spp. and Typha domingenseis (Bini et al., 1999; Tanaka et al., 2002; Marcondes et al., 2003; Bianchini Jr. et al., 2006, Camargo et al., 2006; Thomaz et al., 2006; Martins et al., 2008).

When primary production overcomes herbivory, the exceeding photosynthetic biomass is channelled through the detritus food web (Kuehn et al., 1999). The detritus decomposition is essentially regulated by external factors such as oxygen and nutrient concentrations, temperature, $\mathrm{pH}$, redox potential (López et al., 1998; Mendelssohn et al., 1999; López-Archilla et al., 2001; Corstanje et al., 2006). The decomposition of macrophyte detritus is also dependent on the chemical composition of tissues. The particulate organic matter (POM $\approx$ lignocellulosic compounds) and dissolved organic matter ( $\mathrm{DOM} \approx$ hydrosoluble compounds) enter the pool of detritus after senescence and death of macrophytes. The metabolism associated with POM and DOM provides essential energy for the operation and metabolic stability of the entire ecosystem (Wetzel, 2001). During decomposition, the POM is processed at different rates; in general, the detritus that accumulate in the sediments basically are constituted by lignocellulosic compounds. As POM and DOM detritus undergo decomposition, organic matter and nutrients are released leading to an increment of oxygen demand due to metabolic processes. Microorganisms mediate decomposition by utilizing a wide variety of organic compounds depending on the environment, extracting energy from organic compounds by fermentation, anaerobic and aerobic respiration. Overall, the decomposition is an important process for aquatic systems because it affects the release rate of nutrients, the accumulation rate of litter in sediments and the state or quality of detritus (Cunha-Santino and Bianchini Jr., 2006). The availability of oxygen used by microorganisms during respiration in aquatic environments has great ecological importance, affecting the nature and the final products of decomposition. Under aerobic conditions, most organic matter is reduced to $\mathrm{CO}_{2}$ (Bertrand et al., 2007), while the remaining fraction contributes to the formation of humic substances and the increment of microorganism biomass, which will also be converted to $\mathrm{CO}_{2}$ over a longer period of time. Thus, the rates of oxygen uptake in aerobic mineralization are related to $\mathrm{CO}_{2}$ production, and the quantity of oxygen consumed generally corresponds to the $\mathrm{CO}_{2}$ released (Berman et al., 2001). Oxygen consumption is also an indirect indication of activity of microorganisms in decomposition (Strauss and Lamberti, 2002). In addition to microorganism activity, physical and chemical parameters affect decomposition, which ultimately determines the rates of mineralization and the cycling of carbon and nutrients, including retention of nutrients in detritus and within the environment (Findlay et al., 2002).

The importance of decomposition to cycling in tropical aquatic ecosystems has motivated this study, in which the kinetics of decomposition under laboratory conditions of a floating-rooted aquatic macrophyte, the Eichhornia azurea, is discussed in terms of the oxygen availability. The processes are modeled mathematically with an iterative procedure associating aspects of forcing functions of the natural system (i.e. aerobic and anaerobic condition) and the dominant species (E. azurea) in the reservoir with kinetics equations. The decay model adopted evaluates the rates with which nutrients and carbon from $E$. azurea are cycled in the Reservoir of the Hydroelectric Power Plant (HPP) Piraju.

\section{Material and Methods}

\subsection{Study area}

The selected reservoir was formed from the dam of Paranapanema River in 2002, being located in the municipality of Piraju (São Paulo State, Brazil; 22K 680.335 UTM 7.432.206). It is now classified as a tropical, oligo-mesotrophic system, with low anthropogenic pressures (UFSCar/ CBA, 2008), small $\left(1-10^{2} \mathrm{~km}^{2}\right)$ and rapidly throughflowing system (retention time less than two weeks) sensu. Straškraba (1999). The water temperature ranges from 18.9 to $25.6{ }^{\circ} \mathrm{C}$ within a year (UFSCar/CBA, 2008). According to limnological assessments between 2003 and 2007, Eichhornia azurea (Sw.) Kunth was among the most frequent in the reservoir (UFSCar/CBA, 2008), prevailing among the aquatic macrophytes 
in this environment (i.e. trophic chains, refuge of animals, detritus sources, etc.). The reservoir always presented high concentrations of dissolved oxygen $\left(7.8 \pm 2.1 \mathrm{mg} . \mathrm{L}^{-1}\right)$; the $\mathrm{pH}$ and electric conductivity of the water were $7.15 \pm 0.37$ and $46.9 \pm 9.6 \mu \mathrm{S} . \mathrm{cm}^{-1}$, respectively. Disappearance depth of the Secchi disk was $2.1 \pm 1.0 \mathrm{~m}$. Dissolved organic carbon varied of 0.87 (August/2006) to $8.22 \mathrm{mg}^{-L^{-1}}$ (February/2007). Total phosphorus and nitrogen average concentration were, respectively, 27 and $643 \mu \mathrm{g} . \mathrm{L}^{-1}$, and in the case of the nitrogen, the organic forms prevailed (ca. 82\%). On the average, the sediments contained $10.2 \%$ of organic matter (UFSCar/CBA, 2008).

\subsection{Sampling procedures and experimental design}

Samples of E. azurea were collected on August, 2004 from several sites within HPP Piraju Reservoir. In the laboratory, the plants were washed with tap water and distilled water to remove the coarse material (e.g. periphyton, sediment particles). Some plant samples were fractionated into stems, leaves and roots, while other samples were maintained in their entirety. The plants were then ovendried $\left(45^{\circ} \mathrm{C}\right)$, fragmented (size ca. $1.5 \mathrm{~cm}$ ) and homogenized according to the proportional parts of each morphological structure. The carbon contents of plant material were quantified using a Carlo Erba CHN elemental analyzer (model EA1110). The water samples used in the assays were collected on November, 2004 and brought immediately to the laboratory to set up the incubations. Decomposition chambers $(\mathrm{n}=72)$ were prepared in the laboratory; 36 were maintained under aerobic conditions (with continuous filtered air bubbling) and 36 under anaerobic conditions. In each chamber $4.0 \mathrm{~g}$ (on dry weight basis; DW) of plant fragments were added to $400.0 \mathrm{~mL}$ of reservoir water previously filtered. The incubations were performed in the dark and at $20.0 \pm 1.2^{\circ} \mathrm{C}$. Considering the kinetics of oxygen consumption for E. azurea (Bitar and Bianchini Jr., 2002) and the maximum amount of available dissolved oxygen in each chamber (ca. $3.28 \mathrm{mg}=[\mathrm{OD}]_{\text {sat }} \times 0.4 \mathrm{~L}$; where $[\mathrm{OD}]_{\text {sat }}$ at $20^{\circ} \mathrm{C}$ and $687 \mathrm{~mm} \mathrm{Hg}=8.21 \mathrm{mg} \cdot \mathrm{L}^{-1}$ ), the mixtures became anaerobic ca. $45 \mathrm{~min}$ after adding the plant fragments to the reservoir water. The incubation chambers used for evaluation of anaerobic decay were maintained closed and were opened only on the sampling days.

Periodically, during 90 days, the material of a flask for each condition (aerobic and anaerobic) was fractionated into particulate organic carbon
(POC) and dissolved (DOC) by pre-filtration and centrifugation (1 hour; $978 \mathrm{~g}$ ). POC samples were oven-dried at $45^{\circ} \mathrm{C}$ until reaching constant weight, and their final masses were determined with the gravimetric method. The organic (DOC) and the inorganic dissolved carbon (DIC) concentrations were determined by combustion (TOC Analyzer Shimadzu, model 5000A). The total inorganic carbon (TIC) derived from organic matter mineralization was calculated by the difference between the initial contents of the plant fragments $($ TOC $=$ total organic carbon ca. $1.64 \mathrm{~g} \mathrm{DW}$ ) and the remaining organic carbon determined on the sampling days $(\mathrm{POC}+\mathrm{DOC})$. The $\mathrm{pH}$ values were determined with the potentiometric method (Digimed model DMPH2) and the electrical conductivity (EC) was measured with a conductivity meter (Digimed, model DM 3).

\subsection{Decomposition kinetics of the detritus}

A set of equations was used to describe the mineralization (Equations 1 to 3) of E. azurea detritus (Bianchini Jr. and Antonio, 2003). The parameterizations were obtained by fitting the temporal evolution of POC, DOC and TIC; the fittings were performed using nonlinear regressions with the iterative algorithm of Levenberg-Marquardt, as suggested by Press et al. (1993).

10) The POC mass loss (leaching and mineralization processes of labile and refractory compounds related with particulate carbon) was determined from (Equation 1):

$\frac{\mathrm{dC}_{\text {POC }}}{\mathrm{dt}}=-\mathrm{k}_{\mathrm{T}} \mathrm{C}_{\text {LSPOC }}-\mathrm{k}_{4} \mathrm{C}_{\text {RPOC }}$

where $\mathrm{C}_{\mathrm{LSPOC}}=$ change per unit time in the amount of POC fractions associated with protoplasmic portions (i.e. labile and soluble compounds); $\mathrm{C}_{\mathrm{RPOC}}=$ change per unit time in the amount of POC refractory portions (e.g. cellulose, lignin); $\mathrm{k}_{\mathrm{T}}=$ rate constant for the total mass loss related to leaching and oxidation of labile compounds $\left(\right.$ day $\left.^{-1}\right) ; \mathrm{k}_{\mathrm{T}}=\mathrm{k}_{1}+\mathrm{k}_{2}\left(\mathrm{k}_{1}=\right.$ leaching rate constant $\left(\right.$ day $\left.^{-1}\right) ; \mathrm{k}_{2}=$ rate constant for the oxidation of labile compounds $\left(\right.$ day $\left.\left.^{-1}\right)\right) ; \mathrm{k}_{4}=$ rate constant for oxidation (mineralization) of refractory materials $\left(\right.$ day $\left.^{-1}\right)$.

$2^{\circ}$ ) Formation and mineralization of DOC (Equation 2):

$\frac{\mathrm{dC}_{\text {DOC }}}{\mathrm{dt}}=\mathrm{k}_{1} \mathrm{C}_{\mathrm{LSPOC}}-\mathrm{k}_{3} \mathrm{C}_{\mathrm{DOC}}$

where: $\mathrm{C}_{\mathrm{DOC}}=$ change per unit time in DOC concentration; $\mathrm{k}_{3}=$ mineralization rate constant for DOC (formation of inorganic substances, $\mathrm{CO}_{2}$ and other gases), day ${ }^{-1}$. 
$\left.3^{\circ}\right)$ Formation of gases and inorganic substances (mineralization) (Equation 3):

$\frac{\mathrm{dC}_{\mathrm{TIC}}}{\mathrm{dt}}=\mathrm{k}_{\mathrm{T}} \mathrm{C}_{\mathrm{LPOC}}+\mathrm{k}_{4} \mathrm{C}_{\mathrm{RPOC}}+\mathrm{k}_{3} \mathrm{C}_{\mathrm{DOC}}$

where: $\mathrm{C}_{\mathrm{TIC}}=$ amount per unit time of total inorganic carbon (e.g. $\mathrm{CO}_{2}$ ).

The half-time $\left(\mathrm{t}_{1 / 2}\right)$ corresponding to the rates of the various processes, i.e. leaching, oxidations of LPOC, DOC and RPOC, were estimated according to Equation 4.

$\mathrm{t}_{1 / 2}=\frac{\ln (0.5)}{-\mathrm{k}}$

where: $\mathrm{k}=$ rate constant for the process (leaching or mineralization) $\left(\right.$ day $\left.^{-1}\right)$.

\section{Results}

The elemental analysis showed that the amount of $\mathrm{C}$ in $E$. azurea tissues was $40.97 \%$. The values of LSPOC, DOC, RPOC, $\mathrm{k}_{\mathrm{T}}, \mathrm{k}_{3}$ and $\mathrm{k}_{4}$, calculated with the proposed model (Equations 1 to 3) are shown in Table 1. During aerobic decomposition of E. azurea there was intense POC losses (13.7\%) in the first day, thus increasing the contents of DOC and inorganic compounds (TIC). After this initial stage, the mineralization of POC and DOC was relatively slow, as shown in Figure 1a. The leaching rate constant $\left(\mathrm{t}_{1 / 2}: 0.35\right.$ day) was 21.9 and 1,089 fold higher than the rate constants for DOC and POC mineralization, respectively (Table 1 ), being in the same magnitude that labile POC oxidation $\left(t_{1 / 2}=0.21\right.$ day $)$. The kinetics model fitted the experimental data with a high correlation coefficient $\left(r^{2}: 0.93\right)$. From these results one noted that the slow pathway (driven by $\mathrm{k}_{4}$ ) was the mineralization of this aquatic macrophyte, as the detritus contained mainly refractory compounds (RPOC: $84.3 \%$; Table 1).

The evolution of POC, DOC and TIC in Figure $1 \mathrm{~b}$ indicates that the anaerobic decomposition of $E$. azurea has similar $\left(\mathrm{k}_{\mathrm{T}}\right)$ leaching and/or LPOC mineralization rate constants to the aerobic process $\left(1.77\right.$ day $\left.^{-1}\right)$, with lower mineralization coefficients (Table 1). These rate constants yielded the following mineralization half-times: $\mathrm{k}_{\mathrm{T}}: 0.39$ day; $\mathrm{k}_{3}$ : 6931 days; $\mathrm{k}_{4}$ : 462 days. Analogously to the aerobic decay, the main mineralization pathway was related with RPOC decay (84.7\%). The kinetic

Table 1. Parameters of kinetic model (Equations 1 to 3). Where: LSPOC = particulate organic carbon (POC) fractions associated with protoplasmic portions (labile and soluble compounds); RPOC = POC refractory portions (e.g. cellulose, lignin); DOC = dissolved organic carbon; LPOC = POC labile compounds; TIC = total inorganic carbon; $\mathrm{k}_{\mathrm{T}}=$ rate constant for the total mass loss related to leaching and oxidation of labile compounds $\left[\mathrm{k}_{\mathrm{T}}=\mathrm{k}_{1}+\mathrm{k}_{2}\left(\mathrm{k}_{1}=\right.\right.$ leaching rate constant; $\mathrm{k}_{2}=$ rate constant for the oxidation of labile compounds)]; $\mathrm{k}_{3}=$ mineralization rate constant for DOC; $\mathrm{k}_{4}=$ rate constant for oxidation (mineralization) of refractory materials.

\begin{tabular}{|c|c|c|c|c|c|c|c|c|c|c|}
\hline Resource & $\mathrm{O}_{2}$ & $\begin{array}{c}\text { LSPOC } \\
(\%)\end{array}$ & $\begin{array}{c}\text { Error } \\
(\%)\end{array}$ & $\begin{array}{c}k_{\mathrm{T}} \\
\left(\text { day }^{-1}\right)\end{array}$ & $\begin{array}{c}\text { Error } \\
\left(\text { day }^{-1}\right) \\
\end{array}$ & $\begin{array}{c}\text { RPOC } \\
(\%)\end{array}$ & $\begin{array}{c}\text { Error } \\
(\%)\end{array}$ & $\begin{array}{c}k_{4} \\
\left(\text { day }^{-1}\right)\end{array}$ & $\begin{array}{c}\text { Error } \\
\left(\text { day }^{-1}\right)\end{array}$ & $\begin{array}{c}r^{2} \\
(1)\end{array}$ \\
\hline \multirow[t]{2}{*}{ Leaf } & - & 16.3 & 2.4 & 1.66 & 0.76 & 83.6 & 1.1 & 0.0011 & 0.0031 & 0.94 \\
\hline & + & 18.5 & 2.7 & 1.37 & 0.58 & 81.5 & 1.3 & 0.0008 & 0.0004 & 0.92 \\
\hline \multirow[t]{2}{*}{ Stem } & - & 18.5 & 0.6 & 0.40 & 0.03 & 81.2 & 0.0 & 0.0006 & 0.0001 & 0.99 \\
\hline & + & 18.2 & 1.6 & 0.33 & 0.07 & 81.6 & 1.2 & 0.0015 & 0.0003 & 0.98 \\
\hline \multirow[t]{2}{*}{ Root } & - & 7.9 & 2.1 & 0.76 & 0.53 & 92.5 & 1.2 & 0.0010 & 0.0003 & 0.90 \\
\hline & + & 5.8 & 1.4 & 0.72 & 0.46 & 94.2 & 0.8 & 0.0014 & 0.0002 & 0.96 \\
\hline \multirow[t]{2}{*}{ E. azurea } & - & 15.4 & 2.5 & 1.77 & 0.95 & 84.7 & 1.2 & 0.0015 & 0.0003 & 0.94 \\
\hline & + & 15.7 & 2.2 & 1.96 & 0.97 & 84.3 & 1.0 & 0.0018 & 0.0003 & 0.96 \\
\hline Resource & $\mathrm{O}_{2}$ & $\begin{array}{c}\mathrm{DOC} \\
(\%)\end{array}$ & $\begin{array}{c}\text { Error } \\
(\%)\end{array}$ & $\begin{array}{c}k_{3} \\
\left(\text { day }^{-1}\right)\end{array}$ & $\begin{array}{l}\text { Error } \\
\left(\text { day }^{-1}\right)\end{array}$ & $\begin{array}{c}\text { LPOC } \\
(\%)\end{array}$ & $r^{2}(2)$ & TIC-r ${ }^{2}$ & Obs $\times$ Cal & \\
\hline \multirow[t]{2}{*}{ Leaf } & - & 16.1 & 1.4 & 0.0076 & 0.0028 & 0.2 & 0.78 & 0.72 & 0.85 & \\
\hline & + & 16.4 & 1.4 & 0.0206 & 0.0051 & 2.1 & 0.85 & 0.87 & 0.97 & \\
\hline \multirow[t]{2}{*}{ Stem } & - & 9.6 & 1.5 & 0.0086 & 0.0050 & 8.9 & 0.47 & 0.88 & 0.94 & \\
\hline & + & 18.1 & 3.6 & 0.1201 & 0.0407 & 0.1 & 0.74 & 0.94 & 1.01 & \\
\hline \multirow[t]{2}{*}{ Root } & - & 2.9 & 0.5 & 0.0121 & 0.0066 & 5.0 & 0.53 & 0.85 & 1.01 & \\
\hline & + & 2.0 & 0.4 & 0.0202 & 0.0104 & 3.8 & 0.39 & 0.96 & 0.98 & \\
\hline \multirow[t]{2}{*}{ E. azurea } & - & 10.5 & 1.0 & 0.0001 & - & 4.9 & 0.52 & 0.87 & 1.17 & \\
\hline & + & 10.6 & 2.3 & 0.0896 & 0.0415 & 5.1 & 0.69 & 0.93 & 1.02 & \\
\hline
\end{tabular}

$\mathrm{r}^{2}(1)=$ determination coefficients from the fitting the data to Equation 1 (POC loose of mass); $\mathrm{r}^{2}(2):=$ determination coefficients from the fitting the data to Equation 2 (DOC formation and mineralization); TIC- $\mathrm{r}^{2}$ : determination coefficients from the fitting the data to Equation 3 (sum of IC derived from the 3 mineralization pathways). Obs $\times$ Cal: (linear) relation between the experimental and calculated TIC results. 
model was adequate to fit the TIC data under anaerobic conditions, with $\mathrm{r}^{2}=0.87$ obtained from the (linear) regression that used simulated and experimental values. The differences between the observed and the predicted values in the model were within 1 and $6 \%$, according to Table 2, with the largest variations in the mineralization of leaves

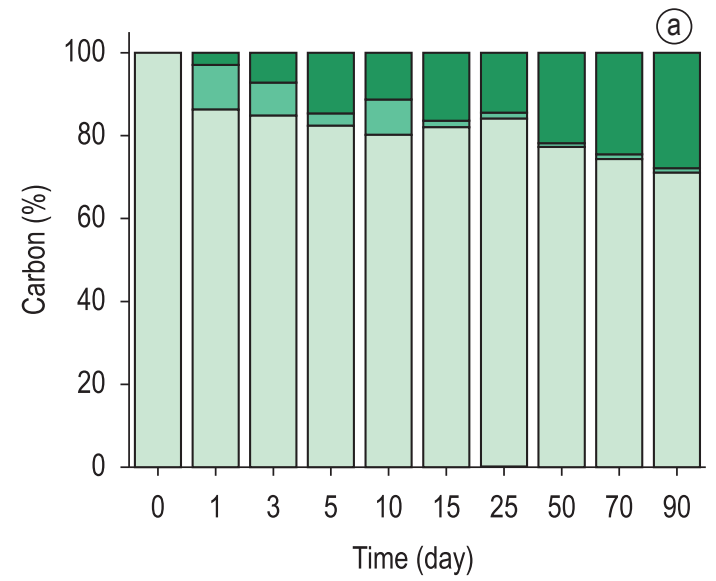

under aerobic condition (15\%) and of E. azurea under anaerobic condition (17\%). From the accumulated carbon mineralized from E. azurea detritus, we obtained a 2.17-fold faster aerobic process in comparison to the anaerobic one. As for the decay of leaves, stems and roots, the aerobic processes were 1.22-fold faster.

$\square$ TIC $\square$ DOC $\square$ POC

Figure 1. Aerobic (a) and anaerobic (b) decomposition of Eichhornia azurea: variations of particulate organic carbon (POC), dissolved organic carbon (DOC) and total inorganic carbon (TIC).

Table 2. LSPOC (labile-soluble particulate organic carbon), RPOC (refractory particulate organic carbon, $\mathrm{k}_{\mathrm{T}}$ (total loose mass constant rate related with LSPOC) and $\mathrm{k}_{4}$ (mineralization of RPOC constant rate) estimated to the adopted model (Equation 1) from decomposition studies of Eichhornia under different environmental conditions. Some notes about the studies and/or experimental conditions are presented into the parenthesis.

\begin{tabular}{|c|c|c|c|c|c|}
\hline Resource & LSPOC (\%) & $\mathrm{k}_{\mathrm{T}}\left(\right.$ day $\left.^{-1}\right)$ & RPOC (\%) & $\mathrm{k}_{4}\left(\right.$ day $\left.^{-1}\right)$ & References \\
\hline Eichhornia azurea (Paraná River) & 16.8 & 0.2 & 83.2 & 0.0008 & Pagioro and Thomaz (1998) \\
\hline E. azurea (lake) & 8.50 & 0.4 & 91.5 & 0.0022 & Pagioro and Thomaz (1998) \\
\hline E. azurea (drought time) & 25.2 & 1.5 & 74.8 & 0.0082 & Stripari and Henry (2002) \\
\hline E. azurea (rain time) & 18.5 & 1.5 & 81.5 & 0.0128 & Stripari and Henry (2002) \\
\hline E. azurea (anaerobic proc. $-15.0^{\circ} \mathrm{C}$ ) & 24.8 & 1.5 & 75.2 & 0.0001 & Tartaglia (2001) \\
\hline E. azurea (anaerobic proc. $-20.0^{\circ} \mathrm{C}$ ) & 23.7 & 1.5 & 76.3 & 0.0004 & Tartaglia (2001) \\
\hline E. azurea (anaerobic proc. $-25.0^{\circ} \mathrm{C}$ ) & 25.9 & 1.5 & 74.1 & 0.0009 & Tartaglia (2001) \\
\hline E. azurea (anaerobic proc. $-30.0^{\circ} \mathrm{C}$ ) & 26.4 & 1.5 & 73.6 & 0.0012 & Tartaglia (2001) \\
\hline E. azurea (anaerobic proc. $-18.2^{\circ} \mathrm{C}$ ) & 24.9 & 1.5 & 74.6 & 0.0001 & Bitar (2003) \\
\hline E. azurea (anaerobic proc. $-21.4^{\circ} \mathrm{C}$ ) & 23.9 & 1.5 & 75.8 & 0.0009 & Bitar (2003) \\
\hline E. azurea (anaerobic proc. $-24.8^{\circ} \mathrm{C}$ ) & 25.7 & 0.6 & 74.7 & 0.0005 & Bitar (2003) \\
\hline E. azurea (anaerobic proc. $-26.8^{\circ} \mathrm{C}$ ) & 25.4 & 1.5 & 74.6 & 0.0005 & Bitar (2003) \\
\hline E. azurea (anaerobic proc. $-20.0^{\circ} \mathrm{C}$ ) & 15.4 & 1.8 & 84.7 & 0.0015 & This study \\
\hline E. azurea (aerobic proc. $-20.0^{\circ} \mathrm{C}$ ) & 15.7 & 2.0 & 84.3 & 0.0018 & This study \\
\hline Average & 21.5 & 1.3 & 78.2 & 0.0023 & \\
\hline Standard deviation & 5.5 & 0.5 & 5.6 & 0.0036 & \\
\hline Eichhornia crassipes (leaves) & 21.8 & 0.6 & 78.2 & 0.0107 & Singhal et al. (1992) \\
\hline E. crassipes (leaves) & 12.8 & 1.2 & 87.2 & 0.0055 & Singhal et al. (1992) \\
\hline E. crassipes (drought time) & 20.6 & 3.3 & 79.4 & 0.0010 & Henry and Stripari (2005) \\
\hline E. crassipes (rain time) & 16.2 & 1.5 & 83.8 & 0.0379 & Henry and Stripari (2005) \\
\hline E. crassipes (near Paraná river) & 0.0 & 0.0 & 100.0 & 0.0400 & Neiff et al. (2006) \\
\hline E. crassipes (oxbow lake) & 6.7 & 0.1 & 93.7 & 0.0205 & Neiff et al. (2006) \\
\hline E. crassipes (palm swamp forest) & 4.3 & 1.5 & 95.7 & 0.0163 & Neiff et al. (2006) \\
\hline Average & 11.8 & 1.2 & 88.3 & 0.0188 & \\
\hline Standard deviation & 8.4 & 1.1 & 8.4 & 0.0152 & \\
\hline Average of genus & 18.2 & 1.3 & 81.6 & 0.0078 & \\
\hline Standard deviation & 7.9 & 0.7 & 8.0 & 0.0119 & \\
\hline
\end{tabular}


Regardless of the experimental condition (aerobic or anaerobic), on average $15.6 \%$ of the E. azurea detritus comprised labile/soluble compounds, of which 10.6 and $5.0 \%$ would constitute the soluble and labile fractions, respectively (Table 1). The LSPOC mass loss was shown to be very fast, in

(a)

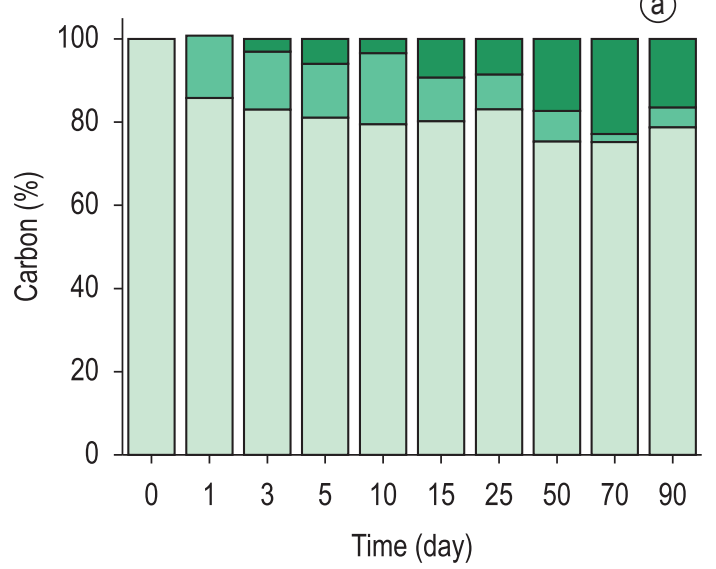

(C)

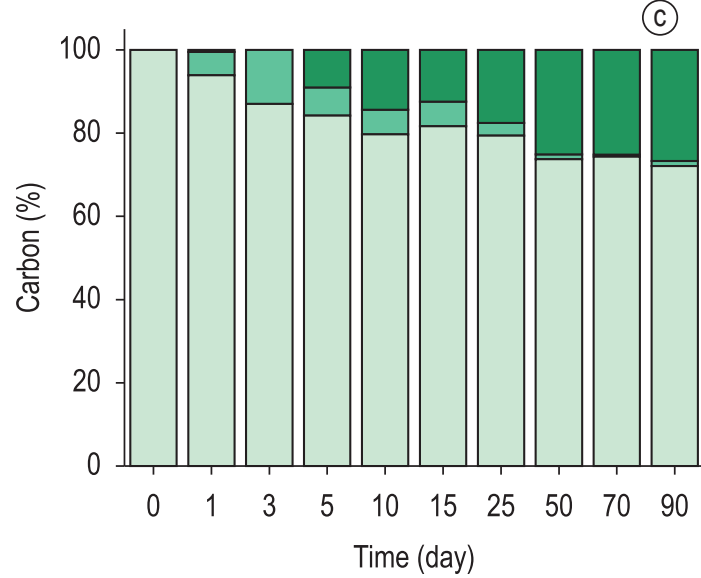

(e)

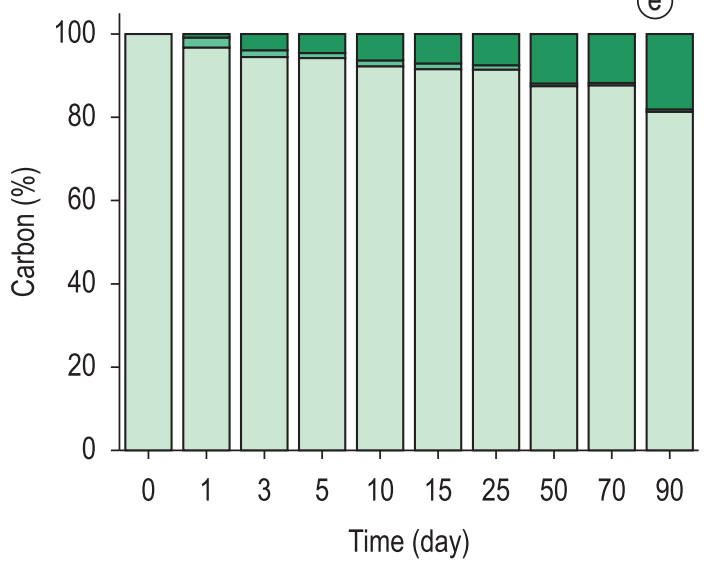

comparison to other reactions such as DOC and RPOC mineralization. The decomposition of the structures of $E$. azurea depended on the type of structure and experimental condition (Figure 2). For the entire plant, the rate constants were higher for the aerobic environment, the refractory content
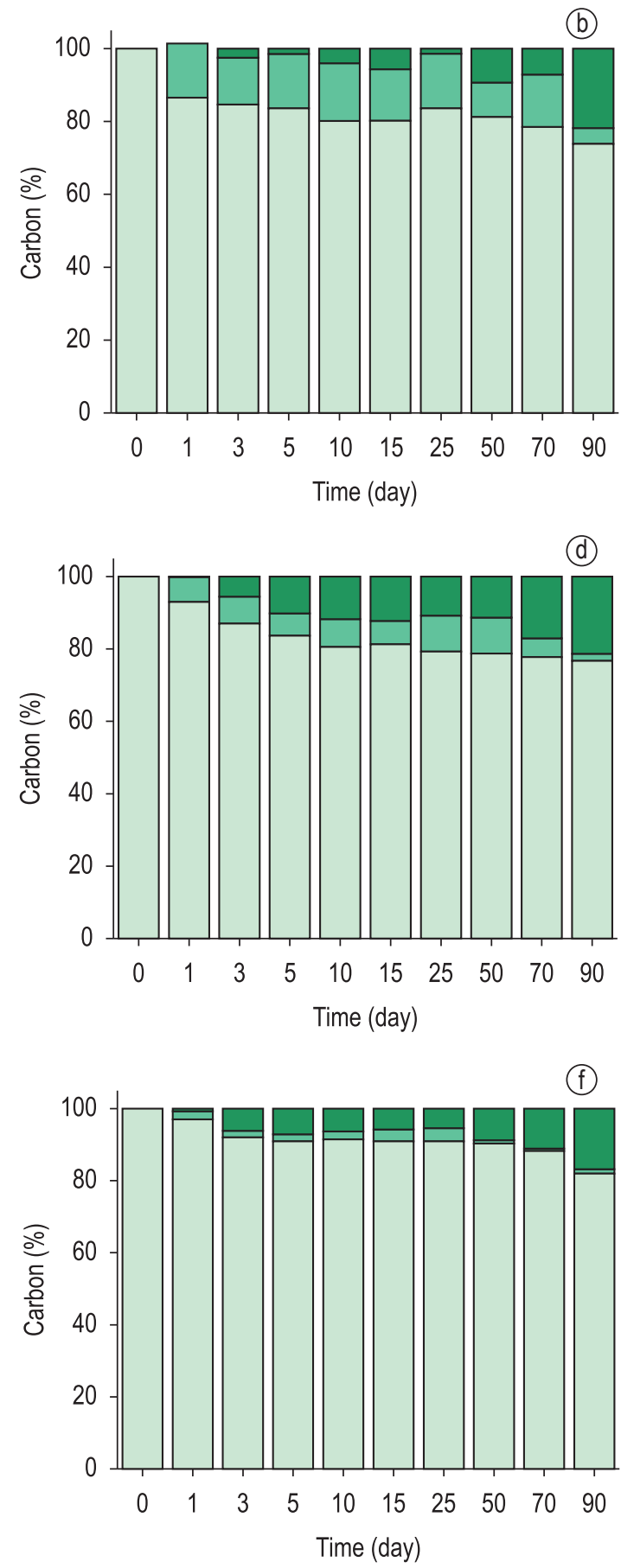

$\square$ TIC $\square$ DOC $\square \mathrm{POC}$

Figure 2. Variations of POC, DOC and TIC during the decomposition of leaves (aerobic (a) and anaerobic (b)), stems (aerobic (c) and anaerobic (d)) and roots (aerobic (e) and anaerobic (f)) of Eichhornia azurea under laboratory conditions. 
(RPOC) varied from 81.2 (stem) to $94.2 \%$ (root); the labile carbon content (LPOC) changed between 0.1 to $5.0 \%$ and the carbon leachate varied from 5.8 to $18.5 \%$. In contrast, for LSPOC, RPOC, DOC and LPOC, the parameters used in the model did not change considerably with the experimental condition, with significant variation being observed mainly between the distinct types of structures, i.e. leaf, stem and root. The kinetics model was still adequate to explain the changes in TIC, with $\mathrm{r}^{2}$ varying from 0.72 (anaerobic decay of leaf) to 0.96 (aerobic decay of root). Taking
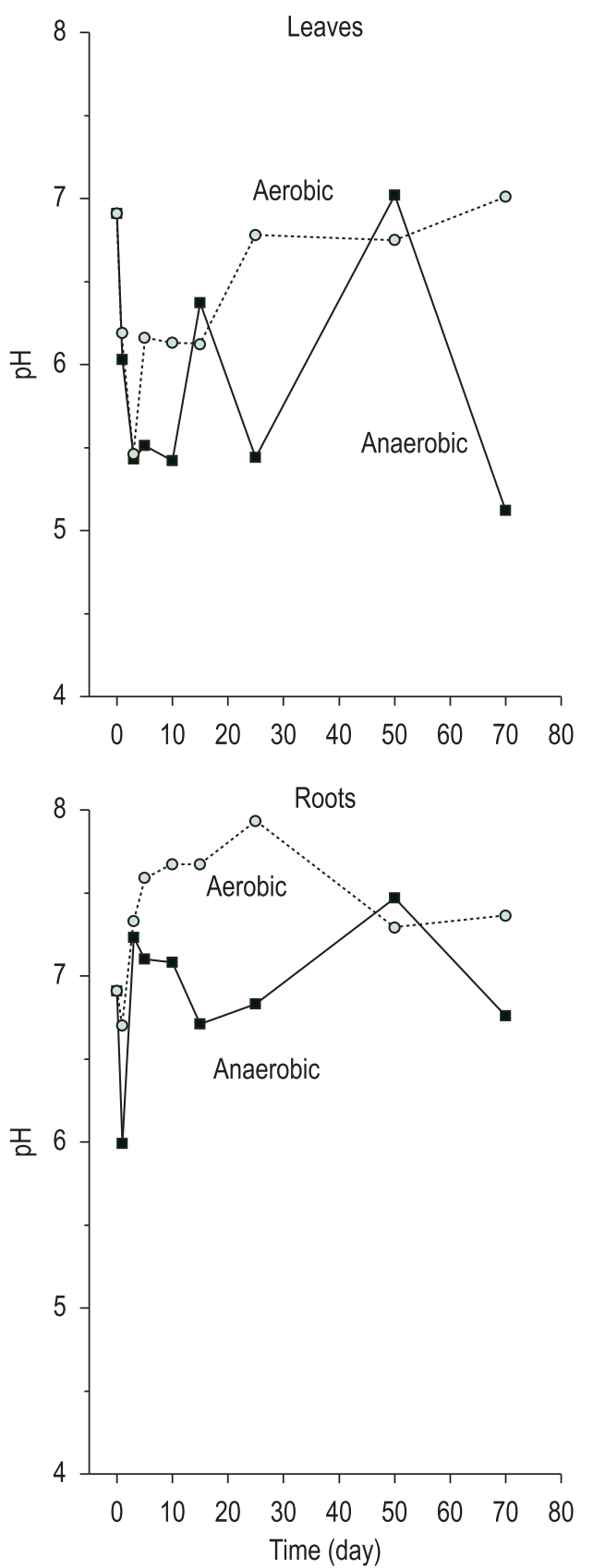

the accumulated carbon mineralized from leaves, stems and roots of Eazurea, the aerobic process was 1.22 times faster than the anaerobic one, while for all the results (E. azurea and structures) the aerobic process was 1.36 -fold faster. The mass loss was similar for the leaves and stems, and higher than for the roots; after the $10^{\text {th }}$ day of incubations a small mass loss was observed.

The $\mathrm{pH}$ varied between 4.44, for E. azurea under anaerobic condition, and 7.87 for the stems under aerobic conditions. As Figure 3 shows, the $\mathrm{pH}$ tended to decrease from the beginning up
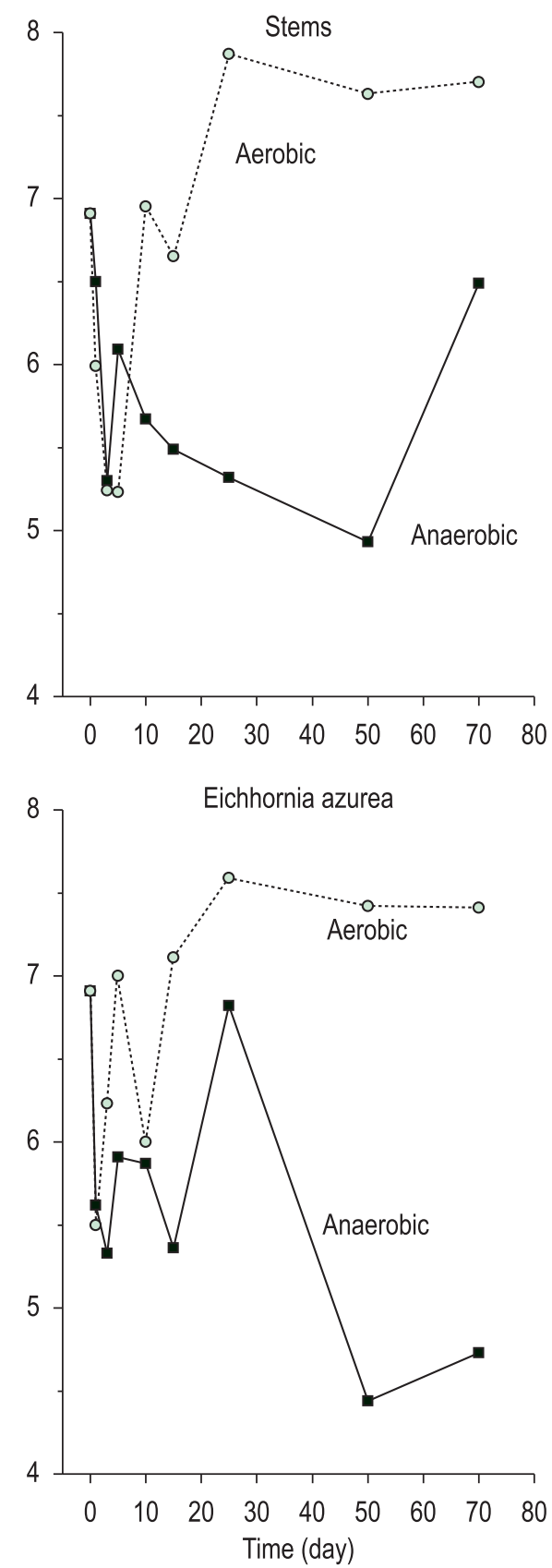

Figure 3. Temporal variations of $\mathrm{pH}$ during the decomposition of leaves, stems, roots and Eichhornia azurea under aerobic and anaerobic conditions. 
to the $10^{\text {th }}$ day, after which it increased. In the incubation under anaerobic conditions the $\mathrm{pH}$ varied considerably in the beginning and then also tended to decrease, with lower values in comparison to those under aerobic incubations.

Figure 4 shows that the electrical conductivity (EC) increased fast in the beginning of all incubations. Then it oscillated and tended to
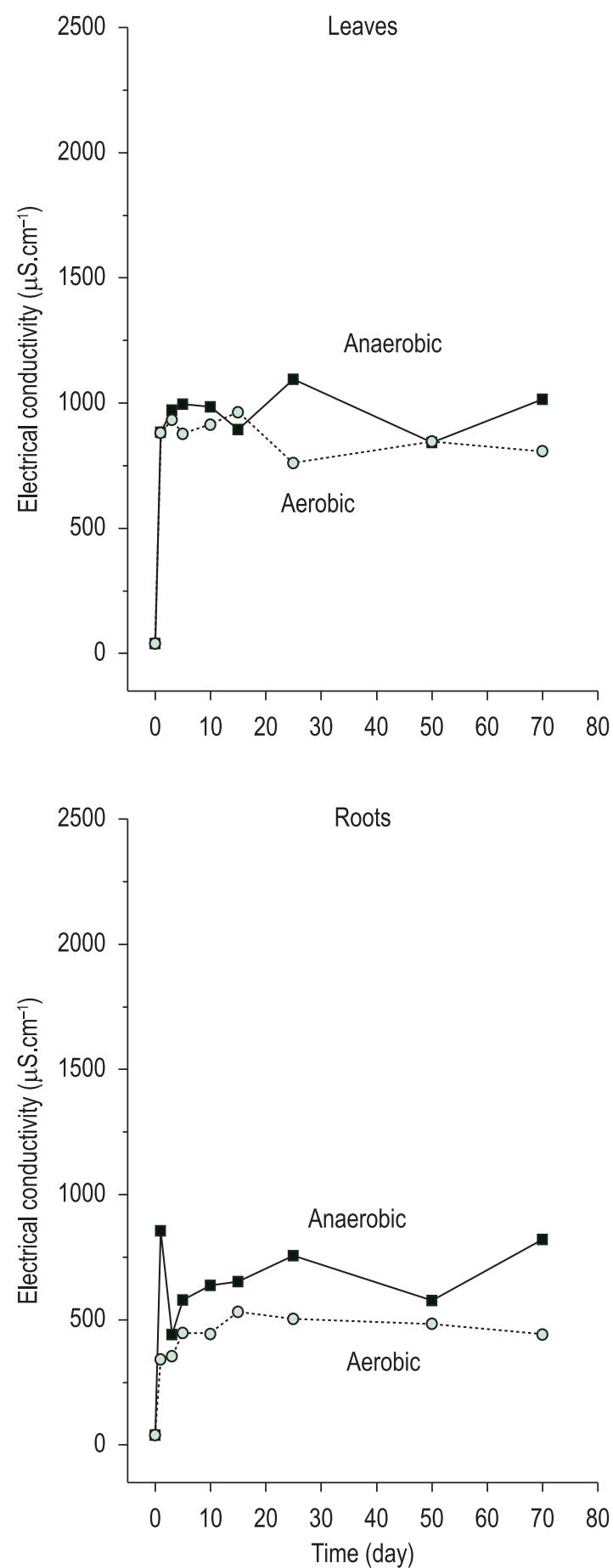

decrease, mainly after the $20^{\text {th }}$ day. The data were similar for aerobic and anaerobic conditions, but in the incubations with E. azurea and its stems, EC were higher (978 to $2,090 \mu \mathrm{S} . \mathrm{cm}^{-1}$ ). The incubations with roots displayed lower conductivities, with the value for the aerobic conditions being the lowest (342 to $533 \mu \mathrm{S} . \mathrm{cm}^{-1}$ ).
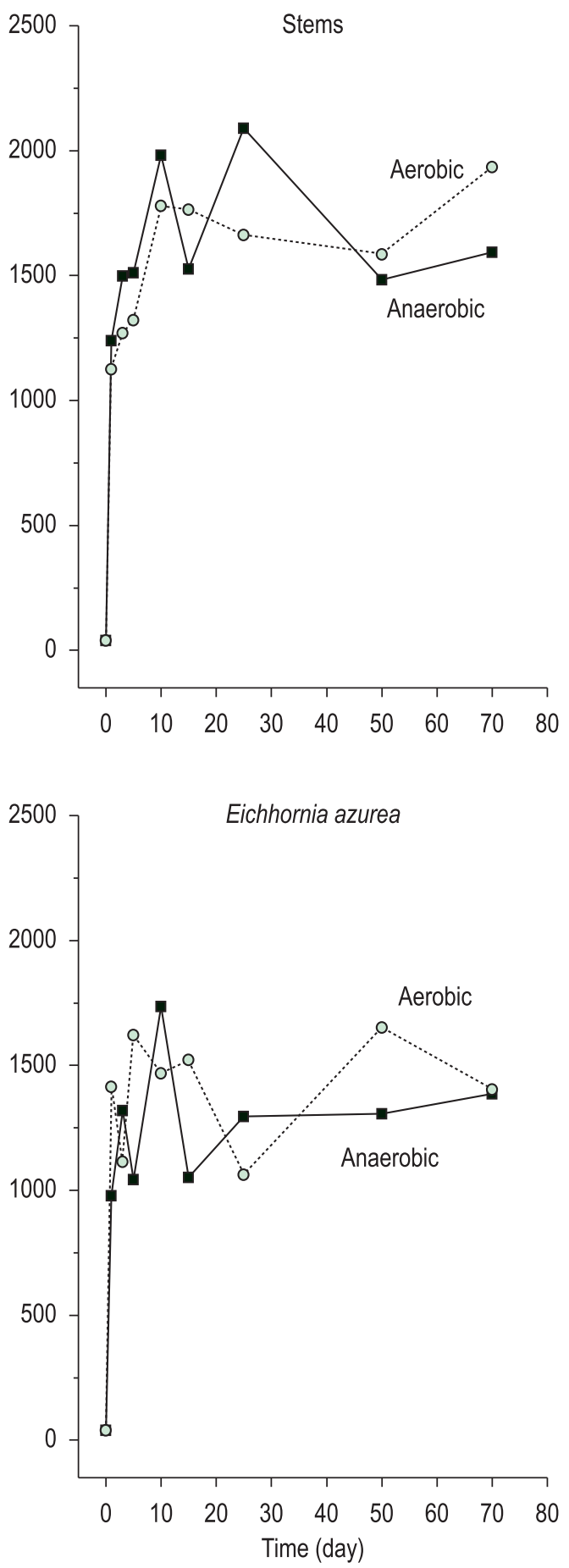

Figure 4. Temporal variations of electrical conductivity during the decomposition of leaves, stems, roots and Eichhornia azurea under aerobic and anaerobic conditions. 


\section{Discussion}

The biphasic exponential model represented in Equation 1 (Lousier and Parkinson, 1976) has been useful to describe the decomposition of aquatic macrophytes, in which the substrate was considered as a heterogeneous resource. With regard to the leaching phase in the decomposition, the leachate prevailed in the first stages of decomposition, being responsible for the intense mass loss shown in Figures 2 and 3, and consequently for the chemical alterations of the detritus. These processes of mass loss are associated with the release of cytoplasm fractions and the hydrosoluble structural compounds (Moorhead et al., 1996; Canhoto and Grace, 1996). Several factors affected the leaching rates, including the experimental procedures (e.g. oven-dry, mesh size of litter bag), abrasion, and chemical composition of the detritus (Park and Cho, 2003). The period of leaching varied from the first 24 hours up to 15 days (Brum and Esteves, 2001; Albariño and Balseiro, 2002; Schlickeisen et al., 2003). The LSPOC and RPOC proportions obtained in this study were a little smaller than for $E$. azurea, while being closer to the proportion presented by E. crassipes, (Table 2 ) which is probably due to the chemical composition of the detritus. The proportion between LSPOC and RPOC indicates that the decomposition of E. azurea detritus has short and long-term effects in the Reservoir of HPP Piraju, thus affecting the release of nutrients, BOD, accumulation of organic matter in the sediment, benthic oxygen demand and the formation of humic substances. The slow processes associated with the RPOC mineralization are predominant.

The release of dissolved compounds is extremely important in aquatic ecosystems, since in these environments the senescent macrophyte biomass is permanently in contact with water (Polunin, 1984). Therefore, these compounds are rapidly incorporated in the DOM pool (Howard-Williams, C. and Howard-Williams, W., 1978). Owing to the large nutrient content and reactive nature of DOC, the leached compounds from decomposing macrophytes tended to be reactive, presenting labile fractions that are readily available to bacteria and phytoplankton metabolism (Sala and Güde, 1999; Faria and Esteves, 2001). These compounds have great potential of incorporation by heterotrophic organisms (Wetzel, 1995). In this context, the increase of TIC and concentrations and electrical conductivity (Figures 1, 2 and 4) can be related to inorganic ions released by leaching, as observed by Mun (2000) in the decomposition of mushrooms, where $\mathrm{Mg}, \mathrm{Ca}, \mathrm{N}, \mathrm{P}, \mathrm{K}$ were intensively released. For the present study the DOC formation and increase of EC (until ca. $5^{\text {th }}$ day) was related to leaching and, in sequence, the decrease of EC and DOC content by heterotrophic uptake.

The second part of Equation 1 (simple exponential model) focuses basically on the refractory fraction, with $\mathrm{k}_{4}$ expressing the mass loss of these compounds (e.g. fibers). The composition and number of microorganisms affect the mineralization rates of the refractory fractions. The values of $\mathrm{k}_{4}$ suggest that, in relation to oxygen availability, the heterotrophic microbiota involved in the aerobic decomposition of lignocellulosic detritus were more efficient that in the anaerobic process. This result was similar to that reported in studies about the cycling of organic resources (Lilleb申 et al., 1999; Cunha-Santino and Bianchini Jr., 2006), in which the aerobic process was usually fast. Breakdown rates reported for Eichhornia RPOC under different experimental conditions (Table 2) fall within the range of 0.0008 to 0.0400 day $^{-1}\left(\mathrm{t}_{1 / 2}=17\right.$ to 866 days $)$, with a mean value of $0.0078 \pm 0.0119$ (SD) day ${ }^{-1}$ $(\mathrm{n}=23)$. The $\mathrm{k}_{4}$ obtained in this experiment were low compared to the decay rates of $E$. crassipes and $E$. azurea obtained when the litter bags method was used (except for the result presented by E. azurea decomposition in Paraná River channel; Pagioro and Thomaz, 1998). Possible reasons for the lower rates could be the influence of external variables or experimental conditions such as photo oxidation, hydrologic regime, temperature and oxygen availability. Other factors such as the season during which the study was performed, stage of maturity of plants at collection, plant parts included in the sample and degree of sample burial must also be considered (Nelson et al., 1990). When considering in situ experiments, the colonization of macroinvertebrates on detritus could represent an additional factor to affect decomposition, especially in temperate ecosystems (Ribas et al., 2006). Also, the decomposition of RPOC could be higher in incubations with litter bags owing to other factors, in addition to the mineralization. For example, effects could arise from the comminution of detritus by action of other organisms, such as macroinvertebrates, abrasion and loss of particles through the litter bags pores. Te $\mathrm{k}_{4}$ parameters for RPOC in this study were higher than in experiments in the laboratory and under anaerobic condition (Tartaglia, 2001; Bitar, 2003), probably for two reasons: i) the chemical composition of $E$. azurea 
tissues and ii) the ability of microbiota to utilize the detritus.

The mean $\mathrm{k}_{4}$ for Eichhornia $\left(0.0078\right.$ day $^{-1}$ in Table 2) is similar to the decay rates for other tropical aquatic macrophytes. From fitting the results with Equation 1, one obtains: 0.0080 day $^{-1}$ for Cabomba furcata (Cunha and Bianchini Jr., 1998); 0.0058 day $^{-1}$ for Egeria najas (Bitar, 2003); 0.0222 day $^{-1}$ for Nymphoides indica (Helbing et al., 1986); 0.0035 day $^{-1}$ for Oxycaryum cubense (Cunha and Bianchini Jr., 1998); 0.0065-0.0240 day ${ }^{-1}$ for Pistia stratiotes (Lopes-Ferreira et al., 2004); 0.0537 day $^{-1}$ for Potamogetum perfoliatus (Hill and Webster, 1982); 0.0104 day $^{-1}$ for Pontederia stenostachys (Lopes-Ferreira and Esteves, 1992); 0.0020-0.0277 $\mathrm{day}^{-1}$ for Salvinia auriculata (Howard-Williams and Junk, 1976; Cunha-Santino and Bianchini Jr., 2000); 0.0020-0.0044 day ${ }^{-1}$ for Typha domingensis (Gonçalves Jr. et al., 2004; Cunha-Santino and Bianchini Jr., 2006) and 0.0021-0.0054 day $^{-1}$ for Utricularia breviscapa (Cunha-Santino and Bianchini Jr., 2008). Owing to the chemical composition and predominance of RPOC over LSPOC, the relative slow decomposition of $E$. azurea fibers points out that this species contributes effectively to the sediment organic matter of HPP Piraju Reservoir. Moreover, one should highlight the abundance and frequency of this species. Considering the three pathways of carbon mineralization, the roots of E. azurea appear to contribute to a larger extent to the enrichment of the organic matter in sediments and less to the DOC pool of reservoir. This conclusion is inferred from the variations of DOC and electrical conductivity in Figures 1, 2 and 4.

The change in $\mathrm{pH}$ in the aerobic incubations in Figure 3 exhibited the same pattern as in the decomposition experiments with Typha domingensis (Cunha-Santino and Bianchini Jr., 2006). After an initial decrease in $\mathrm{pH}$ mainly owing to a high $\mathrm{CO}_{2}$ formation from LPOC oxidation, upon decomposition the $\mathrm{pH}$ increased probably due to the release of anions and other processes such as hydration of ammonia. This process was also reported in the decomposition of Egeria najas (Carvalho et al., 2005) and for T. domingensis (Howard-Williams, C. and Howard-Williams, W.). McKinley and Vestal (1982) reported that in microcosm experiment with Carex litter, reductions below $\mathrm{pH} 5.0$ of lake water increased dramatically the effect on the microbial colonization and decomposition of Carex litter. During aerobic degradation of $E$. azurea the prevalence of a neutral to alkaline environment suggests that a buffer system due to humification was established. It was also proposed that as the degradation proceeded a second buffer system, the carbonate system, coming from the $\mathrm{CO}_{2}$ released by the mineralization, became important. The relative proportion of $\mathrm{CO}_{2}, \mathrm{HCO}_{3}^{-}$and $\mathrm{CO}_{3}^{2-}$ are $\mathrm{pH}$-dependent, and $\mathrm{HCO}_{3}$ - predominated with $\mathrm{pH}$ between 7 and 8 in the aerobic incubations. According to the data in Figure 3, the $\mathrm{pH}$ decreased in the beginning for the anaerobic incubations, being an overall characteristic of an acid media, with intermediate compounds being formed. The fermentation of seeds extract led to a $\mathrm{pH}$ varying between 4 and 6.5 (Schaffner and Beuchat, 1986). During cellulose and cellobiose fermentation, acetic acid was the main volatile organic acid formed (Weimer and Zeikus, 1977). Under this condition the increase in $\mathrm{pH}$ was probably linked to the denitrification reactions (Wetzel, 2001) and the anaerobic ammonium oxidation (Mulder et al., 1995).

In summary, the results presented here pointed to a more efficient cycling of $E$. azurea under aerobic conditions in the HPP Piraju Reservoir. Indeed, from the carbon mineralized, the aerobic processes were 2.17-fold faster than the anaerobic ones. The aerobic decay of E. azurea can promote moderate depletion in the dissolved oxygen budget within the reservoir. Owing to the predominance of RPOC over LSPOC and the time scale of $\mathrm{k}_{4}$ $\left(\mathrm{t}_{1 / 2}=385\right.$ to 462 days $)$, the refractory fractions RPOC, with adequate conditions of $\mathrm{pH}$ and oxireduction potential, contributed to the dynamics of gas production and storage of POC in the sediment. The roots of E. azurea contributed to the enrichment of the organic matter in sediments and less to the DOC pool of the reservoir.

\section{Acknowledgements}

The authors are grateful to Companhia Brasileira de Alumínio (CBA) for the aid in the achievement of water and of plant samples. We thank Dr. Osvaldo N. Oliveira Jr. (IFSC-USP) and two anonymous reviewers, whose comments improved considerably our manuscript.

\section{References}

ALBARIÑO, RJ. and BALSEIRO, EG. 2002. Leaf litter breakdown in Patagonian streams: native vs. exotic trees and the effect of invertebrate size. Aquatic Conservation: Marine and Freshwater Ecosystems, vol. 12, no. 2, p. 181-192. 
BERMAN, T., KAPLAN, B., CHAVA, S., VINER, Y., SHERR, BF. and SHERR, EB. 2001. Metabolically active bacteria in lake Kinneret. Aquatic Microbial Ecology, vol. 23, no. 3, p. 213-224.

BERTRAND, I., DELFOSSE, O. and MARY, B. 2007. Carbon and nitrogen mineralization in acidic, limed and calcareous agricultural soils: apparent and actual effects. Soil Biology and Biochemistry, vol. 39, no. 1, p. 276-278.

BIANCHINI Jr., I. and ANTONIO, RM. 2003. The effect of particle size on the leaching of Scirpus cubensis Poepp and Kunth. Brazilian Journal of Biology, vol. 63, no. 2, p. 195-205.

BIANCHINI Jr., I., BITAR, AL. and CUNHASANTINO, MB. 2006. Crescimento de Egeria najas Planchon da Lagoa do Óleo em condiçôes laboratoriais. In SANTOS, JE., PIRES JS. And MOSCHINI, LE. (Eds.). Estudos Integrados em Ecossistemas - Estação Ecológica de Jataí. São Carlos: FAPESP/Editora UFSCar. p. 99-111.

BINI, LM., THOMAZ, SM., MURPHY, KJ. and CAMARGO, AFM. 1999. Aquatic macrophyte distribution in relation to water and sediment conditions in the Itaipu Reservoir Brazil. Hydrobiologia, vol. 415, no. 1, p. 147-154.

BITAR, AL. 2003. Mineralização e formação de gases da degradaçáo de Eichhornia azurea Kunth e Egeria najas Planch. São Carlos: Universidade Federal de São Carlos, 2003. [Tese de Doutorado].

BITAR, AL. and BIANCHINI Jr., I. 2002. Mineralisation assays of some organic resources of aquatic systems. Brazilian Journal of Biology, vol. 62, no. 4A, p. 557-564.

BRUM, PR. and ESTEVES, FA. 2001. Dry weight loss and chemical changes in the detritus of three tropical aquatic macrophyte species (Eleocharis interstincta, Nymphaea ampla and Potamogeton stenostachys) during decompositon. Acta Limnologia Brasiliensia, vol. 13, no. 1, p. 61-73.

CAMARGO, AFM., PEZZATO, MM., HENRY-SILVA, GG. and ASSUMPÇÃO, AM. 2006. Primary production of Utricularia foliosa, Egeria densa and Cabomba furcata from rivers of the coastal plain of the State of São Paulo, Brazil. Hydrobiologia, vol. 570, no. 1 , p. 35-39.

CANHOTO, C. and GRAÇA, MAS. 1996. Decomposition of Eucalyptus globulus leaves and three native leaf species (Alnus glutinosa, Castanea sativa and Querus faginea) in a Portuguese low order stream. Hydrobiologia, vol. 333, no. 2, p. 79-85.

CARVALHO, P., THOMAZ, SM. and BINI, LM. 2005. Effects of temperature on decomposition of a potential nuisance species: the submerged aquatic macrophyte Egeria najas Planchon (Hydrocharitaceae). Brazilian Journal of Biology. vol. 65, no. 1, p. 51-60.
CORSTANJE, R., REDDY, KR. and PORTIER, KM. Thyph latifolia and Cladium jamaicense litter decay in response to exogenous nutrient enrichment. Aquatic Botany, 2006, vol. 84, no. 1, p. 70-78.

CUNHA, MB. and BIANCHINI Jr., I. 1998. Mineralização aeróbia de Cabomba piauhyensis e Scirpus cubensis. Acta Limnologia Brasiliensia, vol. 10, no. 1, p. 81-91.

CUNHA-SANTINO, MB. and BIANCHINI Jr., I. 2000. Decomposição aeróbia e anaeróbia de Salvinia auriculata da lagoa do Infernão. In SANTOS, JE., PIRES JS. and MOSCHINI, LE. (Eds.). Estudos Integrados em Ecossistemas - Estação Ecológica de Jataí. Sáo Carlos: Rima. p. 631-643.

CUNHA-SANTINO, MB. and BIANCHINI Jr., I. 2006. The aerobic and anaerobic decomposition of Typha domingensis Pers. Acta Limnologia Brasiliensia, vol. 18, no. 3, p. 321-334.

CUNHA-SANTINO, MB. and BIANCHINI Jr., I. 2008. Carbon cycling potential from Utricularia breviscapa decomposition in a tropical oxbow lake (São Paulo, Brazil). Ecological Modelling, vol. 218, no. 3-4, p. 375-382.

FARIA, BM. and ESTEVES, FA. 2001. Dissolved organic carbon in two Brazilian coastal lagoons: sources and utilization for heterotrophic bacteria. Oecologia Brasiliensis, vol. 9, p. 57-64.

FINDLAY, SEG., DYE, S. and KUEHN, KA. 2002. Microbial growth and nitrogen retention in litter of Phragmites australis compared to Typha angustifolia, Wetlands, vol. 22, no. 3, p. 616-625.

GONÇALVES Jr., FJ., SANTOS, AM. and ESTEVES, FA. 2004. The influence of chemical composition of Typha domingensis and Nymphaea ampla detritus on invertebrate colonization during decomposition in a Brazilian coastal lagoon. Hydrobiologia, vol. 527, no. 1, p. 125-137.

HELBING, UW., ESTEVES, FA., TILZER, MM. and STABEL, HH. 1986. Influência dos produtos da decomposição da macrófita aquática Nymphoides indica (L.) O. Kuntze na composição química da água da represa do Lobo (Broa) - São Paulo. Acta Limnologia Brasiliensia, vol. 1, p. 611-637.

HENRY, R. and STRIPARI, NL. 2005. The invertebrate colonization during decomposition of Eichhornia crassipes in the mouth zone of Guareí River into Jurumirim Reservoir (São Paulo, Brazil). The Ekologia, vol. 3, no. 2, p. 1-12.

HILL, BH. and WEBSTER, JR. 1982. Aquatic macrophyte breakdown in an Appalachian river. Hydrobiologia, vol. 89, no. 1, p. 53-59.

HOWARD-WILLIAMS, C. and HOWARDWILLIAMS, W. 1978. Nutrient leaching from the swamp vegetation of Lake Chilwa, a shallow African lake. Aquatic Botany, vol. 4, p. 257-267. 
HOWARD-WILLIAMS, C. and JUNK, WJ. 1976. The decomposition of aquatic macrophytes in the floating meadows of a central Amazonian varzea lake. Biogeographica, vol. 7, p. 115-123.

KUEHN, KA., GESSNER, MO., WETZEL, RG. and SUBERKROPP, K. 1999. Decomposition and $\mathrm{CO}_{2}$ evolution from standing litter of the emergent macrophyte Erianthus giganteus. Microbial Ecology, vol. 38 , no. 1 , p. 50-57.

LILLEB $\varnothing$, AI., FLINDT, M., PARDAL, MA. and MARQUES, JC. 1999. The effect of macrofauna, meiofauna and microfauna on the degradation of Spartina maritima detritus from a salt marsh area. Acta Oecologica, vol. 20, no. 4, p. 249-258.

LOPES-FERREIRA, C. and ESTEVES, FA. 1992. Decomposition of Potamogeton stenostachys Kl. Schum. and evaluation of its detritus as a potential energy source in a tropical lagoon. International Journal of Engineering Science, vol. 18, no. 1, p. $47-54$.

LOPES-FERREIRA, C., CALIJURI, MC., ESPÍNDOLA, ELG. and BIANCHINI Jr., I. 2004. Manejo de uma área alagada do rio Atibaia visando à melhoria da qualidade da água no reservatório de Salto Grande. In ESPÍNDOLA, ELG., LEITE, MA. and DORNFELD, CB. (Eds.). Reservatório de Salto Grande (Americana, SP): caracterização, impactos e propostas de manejo. São Carlos: Rima. p. 397-426.

LÓPEZ, NI., DUARTE, CM., VALLESPINÓS, F., ROMERO, J. and ALCOVERRO, T. 1998. The effect of nutrients additions on bacterial activity in seagrass (Posidonia oceanica) sediments. Journal of Experimental Marine Biology and Ecology, vol. 224, no. 2, p. 155-166.

LÓPEZ-ARCHILLA, AI., MARIN, I. and AMILS, R. 2001. Microbial community composition and ecology of an acidic aquatic environment: the Tinto River, Spain. Microbial Ecology, vol. 41, no. 1, p. 20-35.

LOUSIER, JD. and PARKINSON, D. 1976. Litter decomposition in a cool temperate deciduous forest. Canadian Journal of Botany, vol. 54, no. 5-6, p. 419-436.

MARCONDES, DAS., MUSTAFÁ, AL. and TANAKA, RH. 2003. Estudos para manejo integrado de plantas aquáticas no reservatório de Jupiá. In THOMAZ, SM. and BINI, LM. (Eds.). Ecologia e manejo de macrófttas aquáticas. Maringá: EDUEM, p. 299317.

MARTINS, D., COSTA, NV., TERRA, MA. and MARCHI, SR. 2008. Caracterizaçáo da comunidade de plantas aquáticas de dezoito reservatórios pertencentes a cinco bacias hidrográficas do Estado de São Paulo. Planta Daninha, vol. 26, no. 1, p. 17-32.
McKINLEY, VL. and VESTAL, JR. 1982. Effects of acid on plant litter decomposition in an arctic lake. Applied and Environmental Microbiology, vol. 43, p. 1188-1195.

MENDELSSOHN, IA., SORRELL, BK., BRIX, H., SCHIERUP, H-H., LORENZEN, B. and MALTBY, E. 1999. Controls on soil cellulose decomposition along a salinity gradient in a Phragmites australis wetland in Denmark. Aquatic Botany, vol. 64, no. 3-4, p. 381-398.

MOORHEAD, DL., SINSABAUGH, RL., LIKENS, AE. and REYNOLDS, JF. 1996. Decomposition processes: modeling approaches and applications. Science of the Total Environment, vol. 183, no. 1-2, p. 137-149.

MULDER, A., GRAAF, AA. van de, ROBERTSON, LA. and KUENEN, JG. 1995. Anaerobic ammonium oxidation discovered in a denitrifying fluidized bed reactor. FEMS Microbiology Ecology, vol. 16, no. 3, p. $177-184$

MUN, HT. 2000. Mass loss and changes of mineral nutrients during decomposition of mushrooms, Russula alboaerolata and Lactarius violascens. Korean Journal of Biological Sciences, vol. 4, no. 1, p. 51-55.

NEIFF, AP., NEIFF, JJ. and CASCO, SL. 2006. Leaf litter decomposition in three wetland types of the Paraná River Floodplain. Wetlands, vol. 26, no. 2, p. 558-566.

NELSON, WJ., KADLEC, JA. and MURKIN, HR. 1990. Seasonal comparison of weight for two types of Typha glauca Godr. leaf litter. Aquatic Botany, vol. 37, no. 4, p. 299-314

PAGIORO, TA. and THOMAZ, SM. 1998. Loss of weight and concentration of carbon, nitrogen, and phosphorus during decomposition of Eichhornia azurea in floodplain of the upper Paraná river, Brazil. Brazilian Journal of Biology, vol. 58, no. 4, p. 603-608.

PARK, S. and CHO, KH. 2003. Nutrient leaching from leaf litter of emergent macrophyte (Zizania latifolia) and the effects of water temperature on the leaching process. Korean Journal of Biological Sciences, vol. 7, no. 4, p. 289-294.

POLUNIN, NVC. 1984. The decomposition of emergent macrophyte in freshwater. Advances in Environmental Research, vol. 14, p. 115-166.

PRESS, WH., TEUKOLSKY, SA. VETTERLING, WT. and FLANNERY, BP. 1993. Numerical recipes in C: the art of scientific computing. New York: Cambridge University Press. $994 \mathrm{p}$

RIBAS, ACA., TANAKA, MO. and SOUZA, ALT. 2006. An evaluation of macrofaunal effects on leaf litter breakdown rates in aquatic and terrestrial habitats: a case study in the tropics. Austral Ecology, vol. 31, no. 6, p. 783-790. 
SALA, MM. and GÜDE, H. 1999. Role of protozoans on the microbial ectoenzymatic activity during the degradation of macrophytes. Aquatic Microbial Ecology, vol. 20, no. 1, p. 75-82.

SCHAFFNER, DW. and BEUCHAT, LR. 1986. Fermentation of aqueous plant seed extracts by lactic acid bacteria. Applied and Environmental Microbiology, vol. 51, p. 1072-1076.

SCHLICKEISEN, E., TIETJEN, TE., ARSUFFI, TL. and GROEGER, AW. 2003. Detritus processing and microbial dynamics of an aquatic macrophyte and terrestrial leaf in a thermally constant, springfed stream. Microbial Ecology, vol. 45, no. 4, p. 411-418.

SINGHAL, PK., GAUR, S. and TALEGAONKAR, L. 1992. Relative contribution of different decay processes to the decomposition of Eichhornia crassipes (Mart.) Solms. Aquatic Botany, vol. 42, no. 3, p. 265-272.

STRAŠKRABA, M. 1999. Retention time as a key variable of reservoir limnology. In TUNDISI, JG. and STRAŠKRABA, M. (Eds.). Theoretical reservoir ecology and its applications. São Carlos: International Institute of Ecology, Brazilian Academy of Sciences and Backhuys Publishers. p. 385-410.

STRAUSS, EA. and LAMBERTI, GA. 2002. Effect on dissolved organic carbon quality on microbial decomposition and nitrification rates in stream sediments. Freshwater Biology, vol. 47, no. 1, p. 65-74.

STRIPARI, NL. and HENRY, R. 2002. The invertebrate colonization during decomposition of Eichhornia azurea Kunth in a lateral lake in the mouth zone of Paranapanema River into Jurumirim Resevoir (São Paulo, Brazil). Brazilian Journal of Biology, vol. 62, no. 2, p. 293-310.
TANAKA, RH., CARDOSO, LR., MARTINS, D., MARCONDES, DAS. and MUSTAFÁ, AL. Ocorrência de plantas aquáticas nos reservatórios da Companhia Energética de São Paulo. Planta Daninha, 2002, vol. 20, p. 99-111.

TARTAGLIA, D. 2001. O efeito da temperatura na degradação anaeróbia de Eichhornia azurea. São Carlos: Universidade Federal de São Carlos. [Monografia].

THOMAZ, SM. and BINI, LM. 1999. Ecologia e manejo de macrófias aquáticas em reservatórios. Acta Limnologia Brasiliensia, vol. 10, no. 1, p. 103-116.

THOMAZ, SM., PAGIORO, TA., BINI, LM. and MURPHY, KJ. 2006. Effect of reservoir drawdown on biomass of three species of aquatic macrophytes in a large sub-tropical reservoir (Itaipu, Brazil). Hydrobiologia, vol. 570, no. 1, p. 53-59.

Universidade Federal de São Carlos - UFSCar. 2008. Plano de controle ambiental da Usina Hidrelétrica Piraju: monitoramento da qualidade de águas superficiais e monitoramento e controle das macrófitas aquáticas e de florações de algas (período: agosto/2003 a agosto/2007). São Carlos: Universidade Federal de São Carlos. 115 p. [Relatório técnico].

WEIMER, PJ. and ZEIKUS, JG. 1977. Fermentation of cellulose and cellobiose by Clostridium thermocellum in the absence of Methanobacterium thermoautotrophicum. Applied and Environmental Microbiology, vol. 33, p. 289-297.

WETZEL, RG. 1995. Death, detritus and energy flow in aquatic ecosystems. Freshwater Biology, vol. 33, no. 1, p. 83-89.

WETZEL, RG. 2001. Limnology - Lake and river ecosystems. San Diego: Academic Press/Elsevier. $1006 \mathrm{p}$. 